\title{
Infectious bursal disease virus cloning and structural protein (VP2) expression in Escherichia coli
}

\author{
Sanaullah Sajid ${ }^{1}$, Sajjad ur Rahman ${ }^{1 *}$, Sehrish Nayab ${ }^{1}$, Irfan Ullah Khan ${ }^{2}$ \\ and Asad Javeed ${ }^{2}$ \\ 1. Institute of Microbiology, University of Agriculture, Faisalabad-Pakistan \\ 2. Animal Science Division, Nuclear Institute of Agriculture and Biology, Faisalabad-Pakistan \\ *Corresponding author's email: sajjadrahmanuaf@gmail.com \\ Citation \\ Sanaullah Sajid, Sajjad ur Rahman, Sehrish Nayab, Irfan Ullah Khan and Asad Javeed. Infectious bursal disease \\ virus cloning and structural protein (VP2) expression in Escherichia coli. Pure and Applied Biology. Vol. 9, Issue 1, \\ pp743-749. http://dx.doi.org/10.19045/bspab.2020.90080
}

\begin{tabular}{llll}
\hline \hline Received: 13/09/2019 & Revised: 10/12/2019 & Accepted: 13/12/2019 & Online First: 22/12/2019 \\
\hline
\end{tabular}

\section{Abstract}

Immunosuppressive diseases like infectious bursal disease (IBD) are serious threat to the poultry meat industry. IBD virus consists of two genomic segments in which segment $\mathrm{A}$ encodes all structural and non-structural proteins $(V P 2, V P 3, V P 4)$ and segment B encodes RNA dependent RNA polymerase $V P 1$. In IBD the host immune response is due to the $V P 2$ capsid protein of the virus that leads to the immunosuppression of the birds. In the current research the partial VP2 clones were developed using cRNA based reversed genetic system to understand the molecular determinants of infectious bursal disease virus for pathogenic phenotype and virulence. For the expression analysis, the cloning primers were designed for amplification containing $\mathrm{NdeI}$ and EcoRI restriction sites for the attachment of restriction enzymes. VP2 of the IBDV was expressed in $E$. coli cells with the utilization of pET28a expression vector. Expression analysis of bacterial lysate on SDS-PAGE after IPTG induction of 5 hours with $1 \mathrm{mM}$ concentration, $30 \mathrm{KDa} V P 2$ protein band was observed. This study suggests the use of recombinant $V P 2(r V P 2)$ as a subunit vaccine.

Keywords: Escherichia coli; IBDV; I-ELISA; RT-PCR; rVP2

\section{Introduction}

Gumboro is highly contagious disease of poultry birds. Its causative agent is infectious bursal disease virus that belongs to Avibirnaviridae group of Birnaviridae family. Infectious bursal disease virus (IBDV) is dsRNA non-enveloped virus with a genome having 2 segments $\mathrm{A}$ and $\mathrm{B}$ with diameter of 55-60 nm. Two serotypes of IBDV have been known of which only serotype-I causing disease in birds. Serotype-
II infects several avian species and turkeys but no disease has been reported. Selfcleaved protease encodes the segment $\mathrm{A}$ of IBDV that consists of VP4 and other structural proteins like $p V P 2$ and $V P 3$. $p V P 2$ further yields the $V P 2$ as a major capsid protein. A wide variety of pathotypes of serotype-I have been classified as clinical virulent, subclinical virulent and very virulent groups [1]. 
IBD is known from 1957 and now it is prevalent all over the world. It spreads very quickly in young commercial flock causing immunosuppression that leads to great economic losses. IBD target organ is bursa of Fabricius, where lymphoid cells are mainly infected by the virus that results in reduced feed efficiency and increased mortality. By three to six weeks of age the bursa of Fabricius reaches to its maximum development, at this stage the birds are highly susceptible to this disease and infection results in depletion of lymphoid cells and destruction of bursa [2]. Diagnosis of this disease is possible by virus isolation, Immunofluorescence assay, enzyme linked immunosorbent assay and monoclonal antibody assay. DNA hybridization has been developed for the detection of IBD virus using radioactive and non-radioactive cDNA probes [3]. However, the detection and amplification of the IBD virus can also be done using RT-PCR. Use of two oligonucleotide primers in PCR allow DNA polymerase to produce number of copies of viral DNA by utilizing the template DNA present at the $3^{\prime}$ ends of the primers [4]. IBDV is present in clinical and subclinical forms and birds recovered from virus remains carrier. Virus is resistant to inactivation and there is no control for this disease but vaccination and biosecurity [5].

Considering the above problems in the detection and screening of infectious bursal disease, we aim to produce the $r V P 2$ protein for the development of indirect ELISA and subunit vaccine through recombinant DNA techniques. This article describes the molecular cloning of VP2 genome of infectious bursal disease virus.

\section{Materials and methods}

Isolation of Infectious bursal disease virus Bursa samples infected with infectious bursal disease were collected from outbreaks in the poultry farms located in different areas of district Faisalabad. Suspected bursa tissues from birds showing disease symptoms were triturated in pestle mortar adding $1 \mathrm{ml}$ PBS. Homogenate was subjected to three cycles of freeze and thaw at $-20^{\circ} \mathrm{C}$ to break the cells and centrifuged at $10,000 \times \mathrm{g}$ for 10 minutes at $4^{\circ} \mathrm{C}$. Supernatant was collected from the top layer [6].

\section{Extraction of IBDV RNA}

Viral RNA was extracted using FavorPrep ${ }^{\circledR}$ commercial RNA extraction kit following manufacturer's protocols. Added 150 $\mu 1$ isolated viral supernatant in Eppendorf tube and mixed with $750 \mu 1$ VNE buffer. Vortexed and incubated at room temperature for 10 minutes. Absolute ethanol was added @ $750 \mu \mathrm{l}$ and tube was vortexed again. VNE column from the kit was fixed in the collection tube and all the mixture was centrifuged through the column at $8000 \mathrm{x} \mathrm{g}$ for 1 minute. The flow through was discarded and washed the column with $500 \mu \mathrm{l}$ of wash solution I (available in the kit). Centrifuged and discarded the flow though. The column was washed two times with $750 \mu \mathrm{l}$ wash buffer I I and centrifuged to discard the flow through. The column was fixed in storage tube and eluted the RNA by carefully adding 50 $\mu 1$ elution buffer in the center of the column and incubated for 2 minutes at room temperature. Centrifuged at $8000 \times \mathrm{g}$ for 2 minutes to collect the eluted RNA in storage tube and stored at $-80^{\circ} \mathrm{C}$ [7].

\section{Amplification of VP2 fragment of IBDV} To get the cDNA of IBDV-VP2, $5 \mu 1$ of RNA template was mixed with $1 \mu \mathrm{l}$ random primers, $1 \mu 1 \mathrm{dNTP}$ mix, $7.5 \mu 1$ reaction buffer, $0.5 \mu \mathrm{l}$ RNase ribonuclease inhibitor and $1 \mu \mathrm{l}$ RTase to the final volume of $20 \mu$ l. Reaction was incubated at $25^{\circ} \mathrm{C}$ for 5 minutes and $42^{\circ} \mathrm{C}$ for 50 minutes respectively. The reaction was stopped by incubating at $85^{\circ} \mathrm{C}$ for 5 minutes. $V P 2$ cDNA was amplified through PCR using partial VP2 primers following manufacturer's instructions. The primers BGF: 3'CATATGTGCAGCCGATGATTACC- 
3'and BGR: 3'CCTGGAATTCTCAGGGGAGAGTTG -5' amplified the partial $V P 2$ in segment $A$ of the IBD virus from amino acid sequence 751 to 1449. PCR was run by adjusting the amplification conditions to initial denaturation for 4 minutes at $94^{\circ} \mathrm{C}$ and repetition of 35 cycles including denaturation for 45 seconds at $94^{\circ} \mathrm{C}$, annealing for 45 seconds at $57.6^{\circ} \mathrm{C}$, extension for 90 seconds for $72^{\circ} \mathrm{C}$ and final extension of 10 minutes at $72^{\circ} \mathrm{C}$ [3]. The amplified segment corresponding to VP2 was separated on $1.0 \%$ agarose gel, the expected size of the band was 699 bp [8].

Molecular cloning of $V P 2$ into bacterial expression vector pET28a

The amplified VP2 fragment was cleaved with NdeI and EcoRI at the restriction sites introduced by oligonucleotide primers during synthesis. The isolated VP2 fragment was ligated to bacterial transfer vector pET58a that had also been digested with the same restriction enzymes. The ligated DNA construct pET28a-Vp2 was transformed into E. coli (BL-21) cells and the reaction was carried out at $16^{\circ} \mathrm{C}$ overnight [9].

\section{Colony PCR}

White transparent colonies were picked from all the plates one by one and mixed in $5 \mu \mathrm{l}$ double distilled water in microcentrifuge tubes. PCR reaction mix were prepared in 10 separate microcentrifuge tubes by adding $\mathrm{ddH}_{2} \mathrm{O}(35.5 \mu \mathrm{l}), \mathrm{PCR}$ buffer with magnesium $(5 \mu 1)$, Magnesium sulphate $(3 \mu 1)$, Taq-DNA polymerase $(0.5 \mathrm{ul})$, dNTP $\operatorname{mix}(1 \mathrm{ul}), \mathrm{F}$ primer $(1.2 \mu \mathrm{l})$, R-primer $(1.2 \mu \mathrm{l})$ and DNA template $(2.5 \mu \mathrm{l})$. After pulse centrifugation, the PCR conditions were set as described above. PCR product was run on gel and observed in gel documentation system [10].

\section{Expression analysis of rVP2 protein through SDS-PAGE}

Recombinant VP2 was inoculated on Luria Bertani broth and incubated in shaking incubator at $150 \mathrm{rpm}$ for four hours. The cells were harvested by centrifugation at $1000 \mathrm{x} \mathrm{g}$ for 5 minutes and resuspended in the solution containing $50 \%$ glycerol, $0.6 \mathrm{ml}$ Tris $\mathrm{HCl}$, $0.5 \mathrm{ml}$ B-Mercaptoethanol, $2 \mathrm{ml}$ of $10 \% \mathrm{SDS}$ and $1 \mathrm{ml}$ of $1 \%$ bromophenol blue. To separate the cytoplasmic and nuclear fractions, the cells were passed five times through a 25.5-gauge needle. After centrifugation at $14,000 \mathrm{rpm}$ for 15 minutes and diluted with sample buffer, cytoplasmic and nuclear fractions were separated by SDSPAGE and presence of recombinant VP2 was visualized by Coomassie brilliant blue staining [11].

\section{Results}

\section{Molecular cloning of VP2 of IBDV}

Virulent strains of infectious bursal disease virus were isolated during outbreaks in district Faisalabad. A search for the DNA sequence homology between various strains present at database and the sequence of $r V P 2$ (to be published separately) revealed the short stretched of highly conserved sequence present at the amino terminal ends. Restriction sites were introduced to enable the convenient cloning of the $V P 2$ fragment into bacterial expression vector pET28a (Figure 1). cDNA was prepared corresponding to the partial VP2 fragment and open reading frame of VP2 was amplified by PCR. A 699 bp amplified fragment was digested with $\mathrm{NdeI}$ and EcoRI and subcloned into pET28a (Figure 2) and recombinant $V P 2$ was isolated by colony PCR. (Figure 3). 


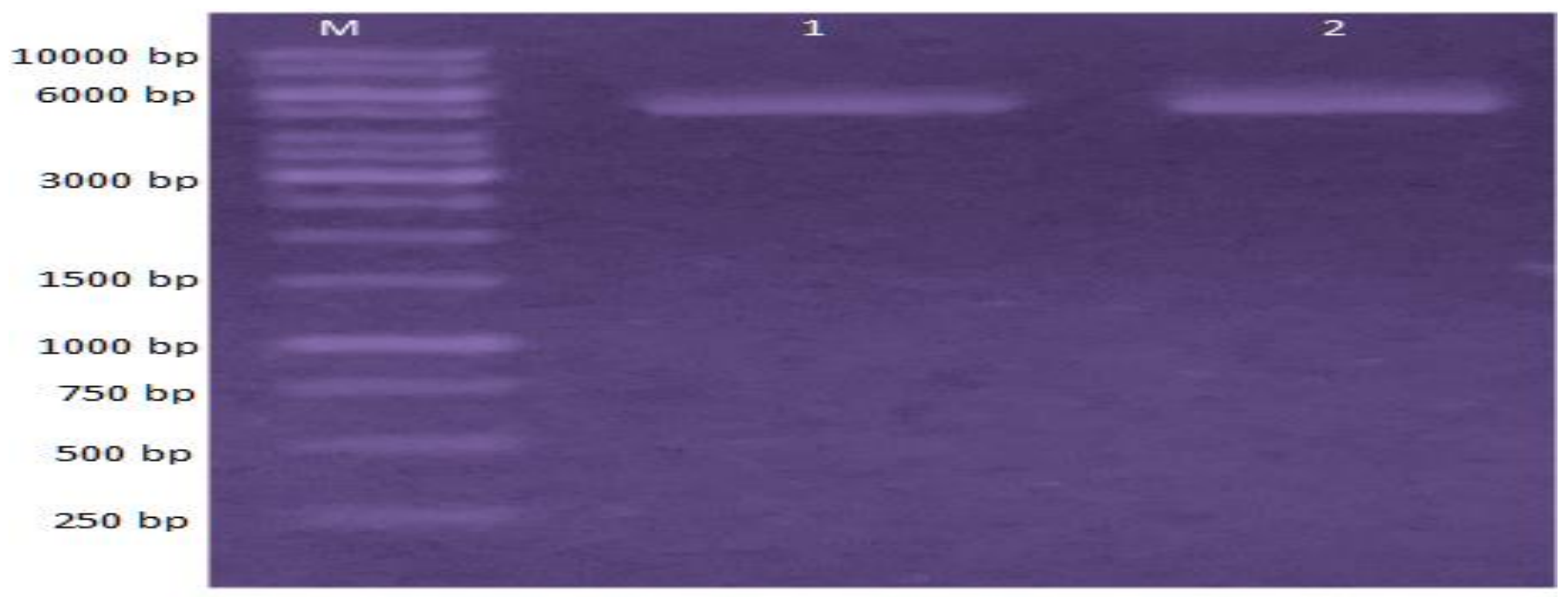

Figure 1. Lane $M$ represents the $1 \mathrm{~kb}$ marker while 1 and 2 represents the plasmid size of $5500 b p$

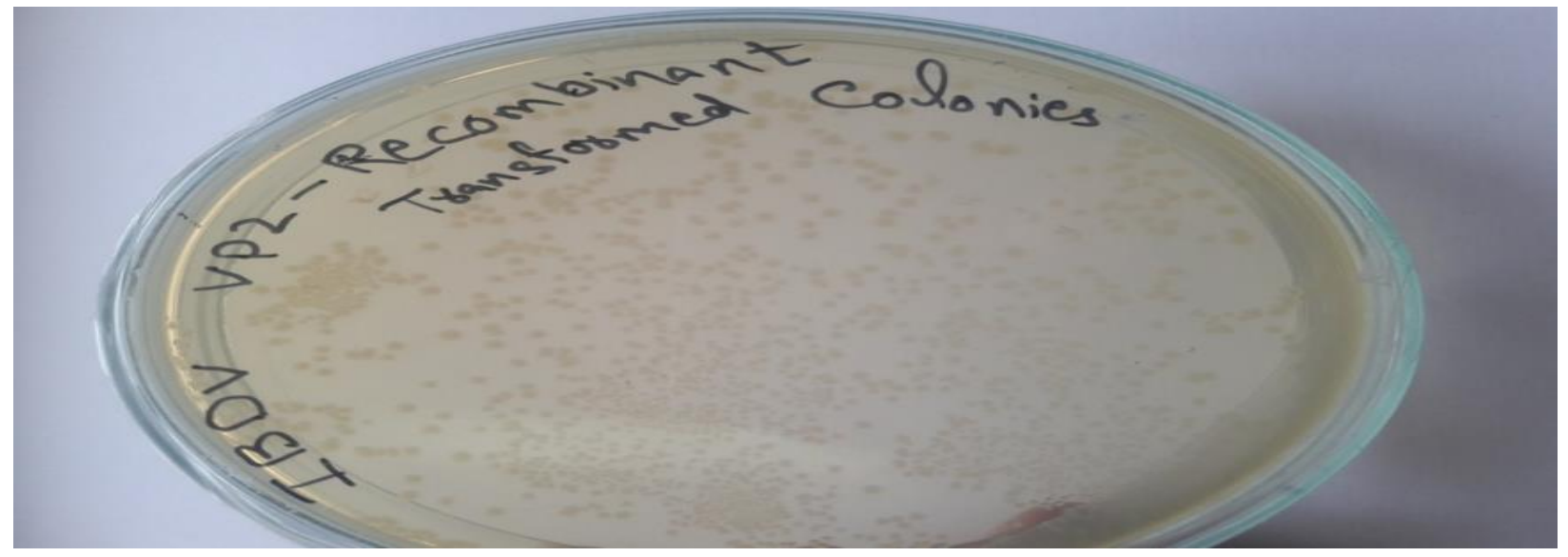

Figure 2. Represents the white transparent colonies $r V P 2$ in $E$. coli cells

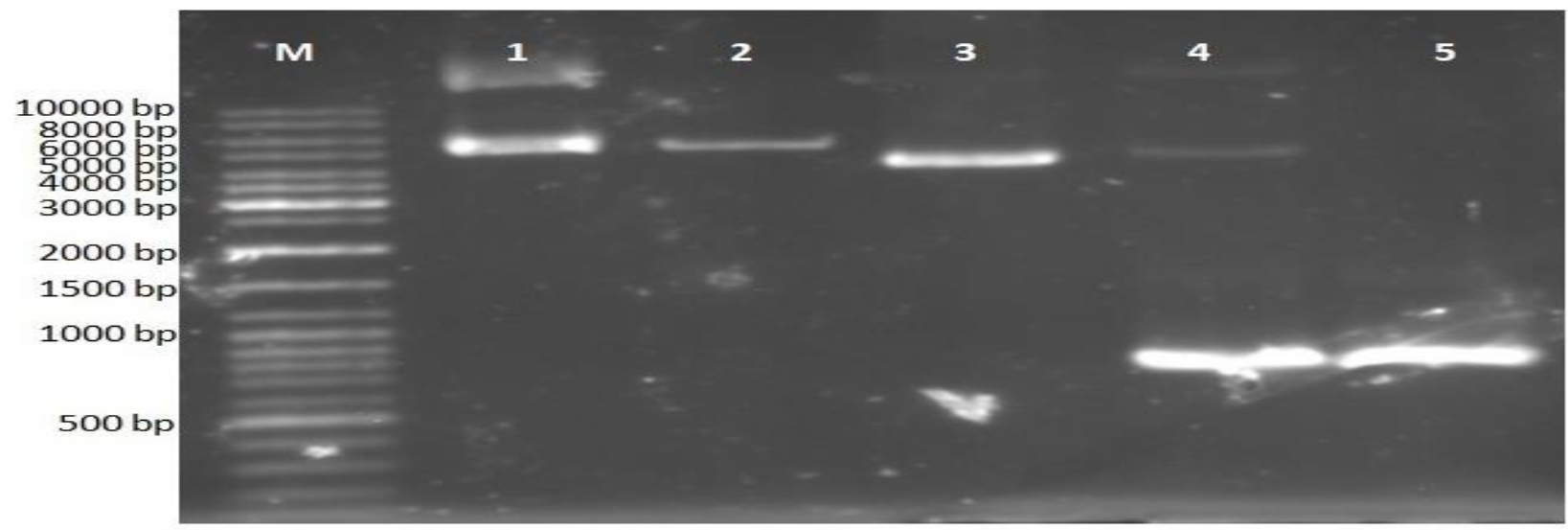

Figure 3. Lane M shows $1 \mathrm{~kb}$ molecular weight marker (Gene Ruler ${ }^{\mathrm{TM}}$ ); Lane 1 shows pET28a (Restricted/ Digested); Lane 2 shows recombinant pET-28a; Lane 3 shows pET-28a plasmid (uncut); Lane 4 shows recombinant plasmid after double digestion which emits a 699 bp clone fragment and Lane 5 shows 699 bp PCR product of partial VP2 region (control) 


\section{Recombinant $V P 2$ Expression analysis by SDS-PAGE}

Expression analysis in sediment and supernatant of $V P 2$ protein was done by SDSPAGE. Sample (30ul) was loaded in the wells of SDS gel after heating for 5 minutes at $90^{\circ} \mathrm{C}$. A current of $150 \mathrm{~V}$ was passed through the gel and Coomassie brilliant blue stain was used to visualize the band with molecular mass of about $30 \mathrm{KDa}[13,14]$. Following the precipitation of the protein fractions with $25 \%$ ammonium sulfate, a strong band of $V P 2$ was detected in cytoplasmic fraction while no VP2 was detected in nuclear fraction of the cells (Figure 4).

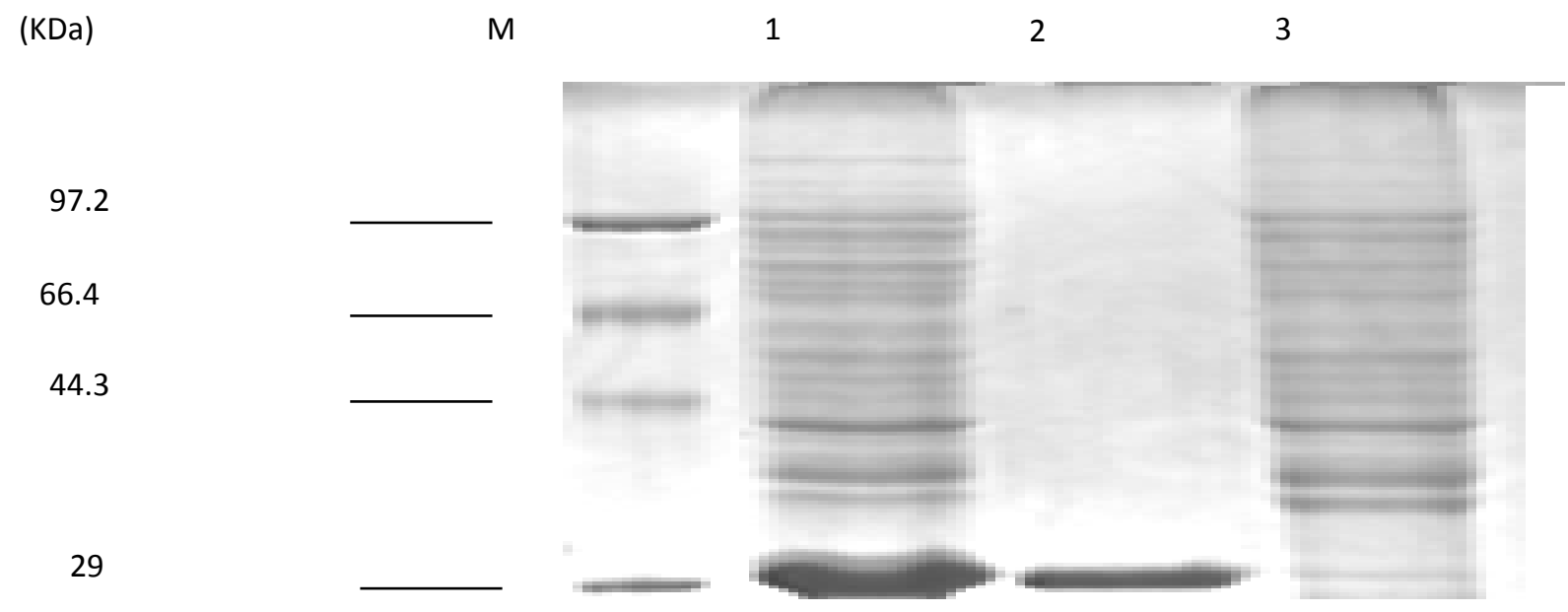

Figure 4. Represents the SDS analysis of Crude and purified $r V P 2 . M$ is the molecular weight marker; Lane 1 shows pET-28a Transformed VP2 cell lysate, IPTG induced $E$. coli; Lane 2 Shows VP2 Purified Protein; Lane 3 shows empty cell lysate from pET-28a

\section{Discussion}

The economic importance of the IBDV in the world's poultry has made it a major pathogen of the poultry birds that leads to immunosuppression due to B cell destruction and secondary bacterial infection. IBD virus consists of two segments includes A constitutes $V P 2, V P 3$ and VP4 while the smaller segment B encodes only $V P 1$. IBD is highly infectious disease and the only control is vaccination $[12,13]$. VP2 segment of the infectious bursal disease virus considered as the most immunogenic region and could be used in the development of vaccine for the effective control of infectious bursal disease in poultry birds to eliminate the major economic losses. Moreover, the detection and screening of IBD is very crucial for the sake of protection of birds. Therefore, the recombinant DNA techniques can be effectively utilized $[14,15]$.

This study focuses on the cloning of $V P 2$ region of infectious bursal disease virus in bacterial expression system. For this purpose, the suspected bursa samples were collected from the outbreaks at poultry farms located in the district Faisalabad. The infectious bursal disease virus was isolated and partial VP2 gene was amplified by Polymerase chain reaction using cloning primers. The purified product was restricted using restriction enzymes and ligated in pET28a expression system. The ligated product was transformed in Escherichia coli cells. SDS-PAGE 
analysis was done for the expression of $r V P 2$ region. The size of $r V P 2$ protein was expected to be larger than the native protein due to the addition of extra amino acids at the carboxyl terminus for cloning procedure.

The $r V P 2$ could be useful in the production of vaccine and the recombinant protein would eliminate the danger inherit in the use of killed or attenuated virus vaccine that is the outbreak of the disease as the result of changes in virus used in vaccine or its incomplete preparation. Immunization with the recombinant vaccine involves the minimum number of antigens essential to stimulate the formation of neutralizing antibodies while preventing the exposure of the antigen that might suppress the immune system. The rVP2 enables the rapid production of a subunit vaccine and it could be easily modified for the rapid response to the virus drift by inserting the gene encoding $V P 2$ of the new variant in to bacterial expression system. Thus, a subunit vaccine against infectious bursal disease virus produced in bacterial expression system may be of great advantage to the poultry industry by stimulating the immediate production of protective antibodies. Another advantage of $r V P 2$ protein is the development of indirect ELISA for the early and possible detection of infectious bursal disease virus antibodies in the serum to determine the immune status of the poultry birds.

\section{Conclusion}

In this study we have expressed the $V P 2$ gene of IBDV in Escherichia coli. Through SDSPAGE analysis, the expected band of 30KDa was detected after gel staining. This recombinant VP2 region is involved in the formation of virus neutralization epitopes and this formation aids in the development of recombinant infectious bursal disease virus vaccines for poultry birds.

\section{Authors' contributions}

Conceived and designed the experiments: $\mathrm{S}$ Sajid \& S Rahman, Performed the experiments: S Sajid \& IU Khan, Analyzed the data: S Nayab, Contributed materials/ analysis/ tools: A Javeed, Wrote the paper: S Sajid.

\section{References}

1. Den BTP (2000). Acute infectious bursal disease in poultry: a review. Avian Pathol 29(3): 175-194.

2. Sharma JM, Kim IJ, Rautenschlein S \& Yeh HY (2000). Infectious bursal disease virus of chickens: pathogenesis and immunosuppression. Dev Comp Immunol 24(3): 223-235.

3. Bughio E, Jatoi AS, Memon M, Bughio R, Khoso PA, Khoso ZA \& Baloch AA (2017). Effect of age and route of administration on the efficacy of various live infectious bursal disease vaccines in broilers. Sarhad J Agric 33(2): 233-239.

4. Eterradossi N, Toquin D \& Meulemans $G$ (2000). Infectious bursal disease (Gumboro disease). Rev - Off Int Epizoot 19(2): 509-543.

5. Phromnoi S, Sinsiri R \& Sirinarumitr T (2010). Expression of recombinant VP2 protein of Canine parvovirus in Escherichia coli. Kasetsart J Nat Sci 44: 870-878.

6. Chen $\mathrm{TH}$, Chen $\mathrm{TH}, \mathrm{Hu} \mathrm{CC}$, Liao JT, Lee CW, Liao JW \& Hsu YH (2012). Induction of protective immunity in chickens immunized with plant-made chimeric Bamboo mosaic virus particles expressing very virulent Infectious bursal disease virus antigen. Virus Res 166(2): 109-115.

7. Michel LO \& Jackwood DJ (2017). Classification of infectious bursal disease virus into genogroups. Arch Virol 162(12): 3661-3670.

8. Jungmann A, Nieper $\mathrm{H}$ \& Müller $\mathrm{H}$ (2001). Apoptosis is induced by infectious bursal disease virus replication in productively infected cells as well as in antigen-negative cells in 
their vicinity. J Gen Virol 82(5): 11071115.

9. Zhu LQ, Wu SL, Zhang GP \& Zhu GQ (2008). The cellular receptors for infectious bursal disease virus. Afr $J$ Biotechnol 7(25): 4832-4835.

10. Vakharia VN, Snyder DB, He J, Edwards GH, Savage PK \& MengelWhereat SA (1993). Infectious bursal disease virus structural proteins expressed in a baculovirus recombinant confer protection in chickens. $J$ Gen Virol 74(6): 1201-1206.

11. Jackwood DJ (2012). Multivalent VirusLike-Particle Vaccine Protects Against Classic and Variant Infectious Bursal Disease Viruses. Avian Dis 57(1): 4150.

12. Pradhan SN, Prince PR, Madhumathi J, Arunkumar C, Roy P, Narayanan RB \& Antony U (2014). DNA vaccination with VP2 gene fragment confers protection against Infectious Bursal Disease Virus in chickens. Vet Microbiol 171(2): 1322.

13. Van den Berg TP, Morales D, Eterradossi N, Rivallan G, Toquin D, Raue R \& Zheng HJ (2004). Assessment of genetic, antigenic and pathotypic criteria for the characterization of IBDV strains. Avian Pathol 33(5): 470-476.

14. Van Loon AAWM, De Haas N, Zeyda I $\&$ Mundt E (2002). Alteration of amino acids in VP2 of very virulent infectious bursal disease virus results in tissue culture adaptation and attenuation in chickens. J Gen Virol 83(1): 121-129.

15. Wang Y, Wu X, Li H, Wu Y, Shi L, Zheng X \& Zhou J (2009). Antibody to VP4 protein is an indicator discriminating pathogenic and nonpathogenic IBDV infection. Mol Immunol 46(10): 1964-1969. 